\title{
Possible Receptor Mechanisms Underlying Cannabidiol Effects on Addictive-like Behaviors in Experimental Animals
}

\author{
Ewa Galaj and Zheng-Xiong Xi * (D) \\ Addiction Biology Unit, Molecular Targets and Medications Discovery Branch, Intramural Research Program, \\ National Institute on Drug Abuse, Baltimore, MD 21224, USA; ewa.galaj@nih.gov \\ * Correspondence: zxi@intra.nida.nih.gov; Tel.: +1-443-740-2517
}

check for

updates

Citation: Galaj, E.; Xi, Z.-X. Possible Receptor Mechanisms Underlying Cannabidiol Effects on Addictive-like Behaviors in Experimental Animals. Int. J. Mol. Sci. 2021, 22, 134. https:/ /dx.doi.org/10.3390/ijms22010134

Received: 16 November 2020 Accepted: 20 December 2020 Published: 24 December 2020

Publisher's Note: MDPI stays neutral with regard to jurisdictional claims in published maps and institutional affiliations.

Copyright: () 2020 by the authors. Licensee MDPI, Basel, Switzerland. This article is an open access article distributed under the terms and conditions of the Creative Commons Attribution (CC BY) license (https: / / creativecommons.org/ licenses/by/4.0/).

\begin{abstract}
Substance use disorder (SUD) is a serious public health problem worldwide for which available treatments show limited effectiveness. Since the legalization of cannabis and the approval of cannabidiol (CBD) by the US Food and Drug Administration, therapeutic potential of CBD for the treatment of SUDs and other diseases has been widely explored. In this mini-review article, we first review the history and evidence supporting CBD as a potential pharmacotherapeutic. We then focus on recent progress in preclinical research regarding the pharmacological efficacy of CBD and the underlying receptor mechanisms on addictive-like behavior. Growing evidence indicates that CBD has therapeutic potential in reducing drug reward, as assessed in intravenous drug selfadministration, conditioned place preference and intracranial brain-stimulation reward paradigms. In addition, $\mathrm{CBD}$ is effective in reducing relapse in experimental animals. Both in vivo and in vitro receptor mechanism studies indicate that CBD may act as a negative allosteric modulator of type 1 cannabinoid (CB1) receptor and an agonist of type 2 cannabinoid (CB2), transient receptor potential vanilloid 1 (TRPV1), and serotonin $5-\mathrm{HT}_{1 \mathrm{~A}}$ receptors. Through these multiple-receptor mechanisms, $\mathrm{CBD}$ is believed to modulate brain dopamine in response to drugs of abuse, leading to attenuation of drug-taking and drug-seeking behavior. While these findings suggest that CBD is a promising therapeutic candidate, further investigation is required to verify its safety, pharmacological efficacy and the underlying receptor mechanisms in both experimental animals and humans.
\end{abstract}

Keywords: cannabidiol; cocaine; CB1 receptor; CB2 receptor; TRPV1; 5-TH; addiction

\section{The History of Medicinal Cannabidiol}

The history of Cannabis sativa (cannabis) reaches to ancient Asia, where the plant was cultivated for religious, medicinal or textile purposes [1,2]. The first medicinal use of cannabis goes back to $4000 \mathrm{BC}$ and relates to the treatment of pain, constipation, menstrual cramps and malaria [3,4]. In the beginning of the Christian Era, cannabis was used together with wine as an analgesic during surgical procedures [1]. The therapeutic use of cannabis was introduced to the Western medicine in the nineteenth century and served as analgesic, anti-inflammatory, anticonvulsant, antiemetic, anesthetic, antitussive, and appetite stimulant [2]. There were also early anecdotal reports that cannabis can alleviate anxiety, depression, mania and other psychological conditions. Despite the apparent therapeutic effects of cannabis, its use in Western medicine decreased significantly in the twentieth century. This decrease was due to several factors, including the discovery of vaccines, more efficacious medications, concerns over cannabis' psychoactive properties and its increasing recreational use [2].

During the rise of modern medicine, cannabis was not recognized among the medical community because of a lack of reliable scientific evidence supporting its efficacy. There was anecdotal evidence that cannabis produced therapeutic effects; however, initial attempts to validate the therapeutic effects of cannabis often fell short. This was due to different strains of cannabis and methods of preparation being used in the studies, making it difficult to 
compare findings across studies and draw comprehensive conclusions. In addition, newly introduced legislation (e.g., the Marijuana Tax Law of 1937, the Controlled Substances Act of 1971) restricted the use of cannabis for medicinal, recreational and experimental purposes [5]. Under these new laws, cannabis was classified as a Schedule I controlled substance, bringing its medicinal use and academic research to a virtual halt.

Despite restrictive registration, the interest in the recreational use of cannabis intensified in the 1960s and 1970s, and scientists were able to isolate its psychoactive and therapeutic constituents [6,7], leading to a new scientific interest in cannabis and its medicinal use. In early 1960s, the Mechoulam lab first isolated and described the structure of cannabidiol (known as CBD) and $\Delta^{9}$-tetrahydrocannabinol ( $\Delta^{9}$-THC) allowing scientists to study their psychoactive and therapeutic effects [6]. In the late 1960s, the Mechoulam group began testing isolated cannabinoids in primates and discovered that $\Delta^{9}-\mathrm{THC}$, but not CBD, causes sedative effects [8]. In 1980, Dr. Mechoulam and colleagues published the results of the clinical trial showing that individuals with severe epilepsy experienced improved conditions after CBD treatment without experiencing any side effects [9]. Unfortunately, despite this breakthrough discovery, this publication was largely ignored among the medical and scientific communities. Some of the reasons pertain to the stigma surrounding cannabis and psychedelics since the 1960s and 1970s.

In 2013 the story of Charlotte Figi surfaced, the little girl who had suffered over 300 grand mal seizures per week, with no medication able to prevent the episodes or reduce their intensity [10]. CBD was reported to eliminate her seizures, saving her life. The story gained national attention and galvanized support for CBD legislation as a medical treatment. In 2014, the Farm Bill (i.e., the Agriculture Act of 2014) was signed into law, legalizing the cultivation of cannabis containing $<0.3 \%$ of $\Delta^{9}$-THC at the state level. Soon some states passed legislation for the legalization of medical CBD, and in 2018, the US Food and Drug Administration (FDA) recognized and approved Epidiolex, the drug containing CBD, for the treatment of seizures associated with pediatric Lennox-Gastaut syndrome or Dravet syndrome, making a significant milestone in modern medicine [11]. The Farm Bill of 2018 legalized the cultivation and sale of hemp at the federal level and officially removed it from the Controlled Substances Act, Schedule I, making research and medicinal development of CBD more accessible.

In the last decade, CBD has gained popularity in the scientific community and its efficacy has been screened for a variety of medical and psychological conditions. The literature provides evidence supporting CBD's therapeutic utility in the treatment of neuropathic pain, epilepsy, inflammation, bacterial infections, nausea, loss of appetite and sleeplessness [12-15]. CBD has been also shown to be effective for neuropsychiatric disorders including substance use disorders (SUDs) [16-20]. There is a number of articles that have reviewed recent research regarding CBD actions against psychostimulants [17,20], opioids [21,22], $\Delta^{9}$-THC [23] and alcohol [24,25] in both humans and experimental animals. However, the majority of them focus on experimental evidence supporting or refuting the use of CBD for the treatment of SUDs, while little attention has been given to recent research regarding the possible receptor mechanisms underlying CBD's action in different animal models of drug abuse and addiction. In this mini-review article, we first briefly review the rationale and major historical events supporting the development of medicinal CBD. We then review more recent findings regarding the pharmacological effects of CBD against opioids, psychostimulants and alcohol, and the involvement of potential receptor mechanisms.

\section{CBD Attenuates Opioid Addictive-Like Behaviors, Possibly through CB1 and 5-HT 1 A Receptor Mechanisms}

Systematic research on the efficacy of CBD on drug addiction did not begin until 1975 when Hine and colleagues published a series of studies demonstrating that CBD can potentiate the pharmacological effects of $\Delta^{9}$-THC to attenuate the physical signs of morphine withdrawal in rats $[26,27]$. Hine et al. found no evidence that CBD alone can attenuate withdrawal symptoms in rats [27], but a year later, another report was 
published demonstrating that CBD reduces naloxone-precipitated withdrawal in mice with a history of morphine exposure [28]. These early studies opened the doors to further exploration of the therapeutic utility of CBD in the treatment of SUDs. In 2009, Hurd's group investigated the effects of CBD treatment on heroin self-administration and relapse in rats. Systemic injections of CBD ( 5 and $20 \mathrm{mg} / \mathrm{kg}$ ) were reported to have no effect on heroin self-administration or drug-primed reinstatement of heroin-seeking [29]. However, CBD was effective in reducing cue-induced reinstatement of heroin-seeking 24 hours and 2 weeks following administration, suggesting that CBD's effect on heroin-seeking is protracted [29].

In a conditioned place preference (CPP) paradigm, when mice were pretreated with CBD prior to a morphine conditioning session, $\mathrm{CBD}$ blocked the development of morphine CPP [30], suggesting that CBD has the ability to block the rewarding effects of opioids and can serve as a preventive therapeutic. When administered prior to the CPP test, CBD reduced the expression of morphine $\mathrm{CPP}$ in rats [31]. In addition, $\mathrm{CBD}$ administered right after the reactivation trials disrupted reconsolidation of drug-reward memory as indicated by the absence of the preference during the drug- or stress-induced reinstatement [31], suggesting that $\mathrm{CBD}$ has the ability to attenuate memories associated with opioid reward and consequently to reduce risks of relapse. In rats with established morphine CPP, CBD blocked conditioned place aversion precipitated by naloxone in the morphine context, suggesting that CBD also has the ability to attenuate the severity of withdrawal symptoms in rats [31].

However, little is known about the mechanisms through which CBD inhibits opioid reward-associated learning and memories, cue-induced heroin-seeking and opioid withdrawal. Ren and colleagues reported that cue-induced heroin-seeking is associated with alterations in the expression of AMPA ( $\alpha$-amino-3-hydroxy-5-methyl-4-isoxazolepropionic acid) GluR1 and the CB1 receptor in the nucleus accumbens (NAc), and such alterations were normalized after the CBD treatment, suggesting that some of CBD's effects against heroin may be mediated by the AMPA and CB1 receptor mechanisms [29]. In addition, other studies showed that CBD reduces the rewarding effects of morphine in an electrical intracranial self-stimulation (ICSS) paradigm and this effect is mediated by serotonin 5$\mathrm{HT}_{1 \mathrm{~A}}$ receptors [32]. Specifically, intra-dorsal raphe infusions of WAY100635, a selective $5-\mathrm{HT}_{1 \mathrm{~A}}$ antagonist, blocked the attenuating effects of $\mathrm{CBD}$, suggesting that $\mathrm{CBD}$ interferes with opioids' action through a $5-\mathrm{HT}_{1 \mathrm{~A}}$ receptor mechanism.

\section{CBD Attenuates Cocaine Addictive-Like Behavior by the CB1, CB2, $5-\mathrm{HT}_{1 \mathrm{~A}}$ and TRPV1 Receptor Mechanisms}

The first empirical studies assessing the efficacy of $\mathrm{CBD}$ against cocaine were published in the 1990s. CBD was shown to protect mice against cocaine- or norcocaine-induced liver hepatotoxicity $[33,34]$. It was two decades later when the therapeutic potential of CBD for cocaine-driven behaviors was evaluated in a systematic way. In the first such study, conducted by Mahmud and colleagues, rats trained to self-administer cocaine under a fixed interval of $20 \mathrm{~s}$ (FI-20 s) and progressive ratio (PR) schedules of reinforcement were treated acutely with CBD either $30 \mathrm{~min}$ or $24 \mathrm{~h}$ prior to the test. CBD (5 and 10 $\mathrm{mg} / \mathrm{kg}$ ) failed to attenuate cocaine self-administration under both schedules and during cue-induced reinstatement [35]. However, other follow-up studies indicated that higher doses of CBD $(15-40 \mathrm{mg} / \mathrm{kg})$ are required to reduce cocaine self-administration [36,37]. Repeated administration of $20 \mathrm{mg} / \mathrm{kg}$ CBD was able to reduce cocaine taking in mice over time [36]. In our recent report, we found that CBD, at 20 and $40 \mathrm{mg} / \mathrm{kg}$, failed to reduce cocaine self-administration maintained by $0.5 \mathrm{mg} / \mathrm{kg} /$ infusion under fixed ratio 1 (FR1) and PR schedules of reinforcement in rats [37]. However, when the cocaine dose was lowered to $0.25 \mathrm{mg} / \mathrm{kg} /$ infusion, CDB significantly attenuated PR response for cocaine. In a self-administration paradigm with multiple cocaine doses that changed within each session, CBD at $20 \mathrm{mg} / \mathrm{kg}$ was effective against the $0.03,0.06$ and $0.12 \mathrm{mg} / \mathrm{kg}$ doses of cocaine, but not 0.25 and $0.5 \mathrm{mg} / \mathrm{kg}$ [37]. 
In regards to other cocaine-related behaviors, $\mathrm{CBD}$ has been shown to block the acquisition of cocaine place preference (CPP) when administered prior to conditioning sessions [36]. In addition, CBD can facilitate the extinction of cocaine- and amphetamineinduced CPP [38]. In rats previously trained for cocaine CPP, CBD disrupted the reconsolidation of cocaine memories and preference when CBD was administered immediately after drug cue exposure [31]. In a brain-stimulation reward (BSR) paradigm, CBD $(20 \mathrm{mg} / \mathrm{kg})$ was shown to block the reward-enhancing effects of cocaine [37] but to have no effect at lower CBD doses [32]. CBD also failed to alter cocaine sensitization when administered alone [36] or in combination with $\Delta^{9}$-THC [39]. However, in a reinstatement test, transdermal application of $\mathrm{CBD}$ for 7 days was shown to be effective in reducing cocaine-seeking in rats with a history of self-administration and this effect persisted for a long time even when the CBD treatment was terminated [40]. Together, these data suggest that CBD has certain therapeutic effects in attenuation of cocaine reward and relapse to drug-seeking behavior.

The receptor mechanisms underlying the above CBD action remain unclear. Early in vitro ligand binding assays indicate that $\mathrm{CBD}$ has low ( $\mu \mathrm{M}$ range) binding affinities to CB1 or CB2 receptor orthosteric binding sites (Table 1). However, more recent receptor binding and multiple intracellular signal functional assays indicate that $\mathrm{CBD}$ has unexpectedly high binding affinity and potency (with $\mathrm{nM}$ of $\mathrm{K}_{\mathrm{i}}, \mathrm{EC}_{50}$ or $\mathrm{IC}_{50}$ values) as a CB1R negative allosteric modulator, $\mathrm{CB} 2$ receptor antagonist/inverse agonist or partial agonist, and TRPV1 and GPR55 agonist (Table 1). Based on these new findings, we have recently explored the roles of CB1, CB2, GPR55, TRPV1, 5- $\mathrm{HT}_{1 \mathrm{~A}}$, and mu opioid receptor (MOR) in CBD's action in multiple animal models related to drug abuse and addiction (Table 2). We found that $\mathrm{CB} 1, \mathrm{CB} 2,5-\mathrm{HT}_{1 \mathrm{~A}}$ and TRPV1 receptors are critically involved in $\mathrm{CBD}$ action in cocaine self-administration, sucrose self-administration, and cocaine-enhanced BSR. In contrast, we did not find evidence supporting the involvement of GPR55 and MOR in CBD's action in cocaine self-administration [37].

Table 1. Cannabidiol (CBD) binding profiles in in vitro binding assays for the receptors or functional molecules involved in drug abuse and addiction.

\begin{tabular}{|c|c|c|c|}
\hline Target & Function & CBD Action & References \\
\hline \multirow[t]{2}{*}{ CB1 } & Antagonist & $\begin{array}{c}\text { Low affinity to CB1Rs in }\left[{ }^{3} \mathrm{H}\right] \mathrm{CP} 55940 \text { binding assay }\left(\mathrm{K}_{\mathrm{i}}=3.3 \sim 4.9\right. \\
\mu \mathrm{M}) ; \\
\downarrow \text { CP55940-enhanced GTP } \gamma \mathrm{S} \text { binding }\left(\mathrm{K}_{\mathrm{B}}=79 \mathrm{nM}\right) ; \\
\downarrow \text { CP55940-induced inhibition of cAMP formation }\left(\mathrm{K}_{\mathrm{B}}=545 \mathrm{nM}\right) ; \\
\downarrow \text { CP55940-induced } \beta \text {-arrestin recruitmrnt in CB1-expressing } \\
\text { HEK-CRE cells }\left(\mathrm{K}_{\mathrm{B}}=547 \mathrm{nM}\right)\end{array}$ & {$[41,42]$} \\
\hline & NAM & $\begin{array}{c}\downarrow \Delta^{9} \text {-THC- or 2-AG efficacy and potency on arrestin2, PLC } \beta 3 \text { and } \\
\text { ERK1/2 signaling in CB1-expressing HEK 293A cells }\left(\text { IC }_{50}=\right. \\
0.27 \sim 0.96 \mu \mathrm{M})\end{array}$ & [43] \\
\hline \multirow[t]{3}{*}{ CB2 } & Antagonist & 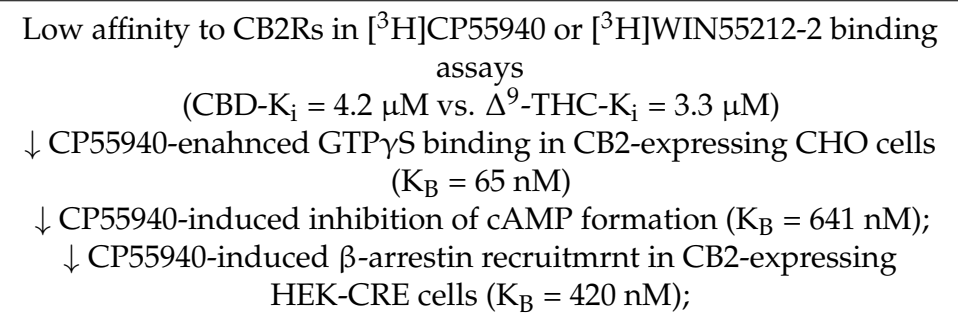 & {$[41,42,44,45]$} \\
\hline & NAM & $\begin{array}{l}\downarrow \text { JWH133-induced reduction in forskolin-stimulated cAMP } \\
\text { formation } \\
\left(\mathrm{IC}_{50}=3 \mathrm{nM}\right) \\
\downarrow \mathrm{JWH} 133 \text {-induced ERK1 } 2 \text { phosphorylation in HEK cells expressed } \\
\text { hCB2 }\left(\mathrm{IC}_{50}=29 \mathrm{nM}\right)\end{array}$ & [44] \\
\hline & Inverse agonist & $\begin{array}{c}\downarrow \mathrm{GTP} \gamma \mathrm{S} \text { binding in CB2-expressing } \mathrm{CHO} \text { cells } \\
\left(\mathrm{EC}_{50}=503 \mathrm{nM}\right)\end{array}$ & [41] \\
\hline
\end{tabular}


Table 1. Cont.

\begin{tabular}{|c|c|c|c|}
\hline Target & Function & CBD Action & References \\
\hline CB2 & Partial agonist & $\begin{array}{c}\left.\text { Unexpectedly high affinity to CB2Rs in }{ }^{3} \mathrm{H}\right] \mathrm{CP} 55940 \text { binding assays } \\
\left.\text { (CBD- } \mathrm{K}_{\mathrm{i}}=34 \mathrm{nM} \text { vs. } \Delta^{9}-\mathrm{THC}-\mathrm{K}_{\mathrm{i}}=15 \mathrm{nM}\right) \\
\uparrow \text { BRET response, } \uparrow \text { intracellular CRE activity in CRE and BRET } \\
\text { assays } \\
\text { in CB2-expressing HEK cells }\end{array}$ & [42] \\
\hline GPR55 & Antagonist & 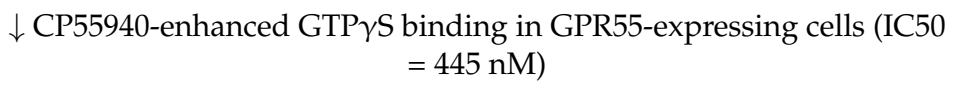 & [45] \\
\hline TRPV1 & Agonist & $\uparrow\left[\mathrm{Ca}^{++}\right]$levels in TRPV1-expressing HEK 293 cells $\left(\mathrm{EC}_{50}=3.5 \mu \mathrm{M}\right)$ & [46] \\
\hline FAAH & Inhibitor & $\begin{array}{c}\downarrow\left[{ }^{14} \mathrm{C}\right] \text { AEA update in N18TG2 cells }\left(\mathrm{IC}_{50}=27.5 \mu \mathrm{M}\right) \\
\downarrow\left[{ }^{14} \mathrm{C}\right] \text { AEA update in HeLa cells expressing rat, but not human, } \\
\text { FAAH at } 50-200 \mu \mathrm{M}\end{array}$ & {$[46,47]$} \\
\hline $5-\mathrm{HT}_{1 \mathrm{~A}}$ & Agonist & $\begin{array}{c}\downarrow\left[{ }^{3} \mathrm{H}\right] 8-\mathrm{OH}-\mathrm{DPAT} \text { binding; } \\
\uparrow \mathrm{GTP} \gamma \mathrm{S} \text { binding in 5-HT} \mathrm{H}_{1 \mathrm{~A}} \text {-expressing } \mathrm{CHO} \text { cells }\end{array}$ & [48] \\
\hline $\mathrm{D} 2$ & Partial agonist & $\begin{array}{l}\downarrow\left[{ }^{3} \mathrm{H}\right] \text { domperidone binding to } \mathrm{D} 2 \text { receptors }(\mathrm{Ki}=11 \mathrm{nM} \text { at } \mathrm{D} 2 \mathrm{High} \\
\mathrm{Ki}=2800 \mathrm{~nm} \text { at D2Low })\end{array}$ & [45] \\
\hline MOR \& DOR & $\begin{array}{l}\text { Allosteric } \\
\text { modulator }\end{array}$ & $\begin{array}{c}\downarrow\left[{ }^{3} \mathrm{DNM}\right] \text { binding to MOR }\left(\mathrm{IC}_{50}=7 \mu \mathrm{M}\right) \\
\text { At } 100 \mu \mathrm{M}, \uparrow\left[{ }^{3} \mathrm{H}\right] \mathrm{DAMGO} \text { dissociation from MOR }\left(\mathrm{pE}_{50}=4.38 \mu \mathrm{M}\right) \\
\uparrow\left[{ }^{3} \mathrm{H}\right] \text {-naltrindole dissociation from DOR }\left(\mathrm{pE}_{50}=4.1 \mu \mathrm{M}\right)\end{array}$ & {$[49,50]$} \\
\hline
\end{tabular}

CRE, cAMP response element; BRET, bioluminescence resonance energy transfer.

\subsection{CB1R Mechanism}

Although CBD has low affinity for the CB1R orthosteric binding site [46], it displays high $\mathrm{nM}$ affinity for the CB1R allosteric binding site and functionally act as a negative allosteric modulator (Table 1, Figure 1) [41-43,51]. CBD pretreatment was reported to be able to reduce the affinity of orthosteric ligands to CB1Rs and CB1R-dependent intracellular signaling such as $\Delta^{9}$-THC- and 2-AG-induced CB1R internalization, $\beta$-arrestin recruitment and phospholipase $C \beta 3$ - and ERK1/2-phosphorylation [41-43,51]. To determine the role of CB1R in CBD's action in experimental animals, we trained mice for oral sucrose selfadministration. We found that systemic administration of CBD $(10,20$, and $40 \mathrm{mg} / \mathrm{kg}$, i.p.) produced a dose-dependent reduction in sucrose self-administration in rats and in wild-type (WT) mice [52]. Unexpectedly, CBD was more efficacious in transgenic CB1 receptor-knockout (CB1-KO) mice than in WT mice. Similarly, pretreatment with AM251 (a selective CB1R antagonist) potentiated CBD-induced reduction in sucrose selfadministration, suggesting that CB1R antagonism may underlie the additive or synergistic effects of CBD on sucrose self-administration [52]. However, not all evidence supports this finding. Pretreatment with AM251 failed to enhance CBD's action in cocaine selfadministration or electrical BSR in rats [37], suggesting that the CB1R antagonism produced by $\mathrm{CBD}$ on the allosteric binding sites is not sufficient in the attenuation of cocaine reward. This is consistent with literature reports that blockade of CB1Rs by AM251 was able to inhibit cocaine self-administration in some reports [37,53,54], but not in others [5559]. In addition, repeated treatment with $C B D$ increases the expression of CB1Rs in the striatum [36], suggesting possible interactions between CBD and CB1Rs. 


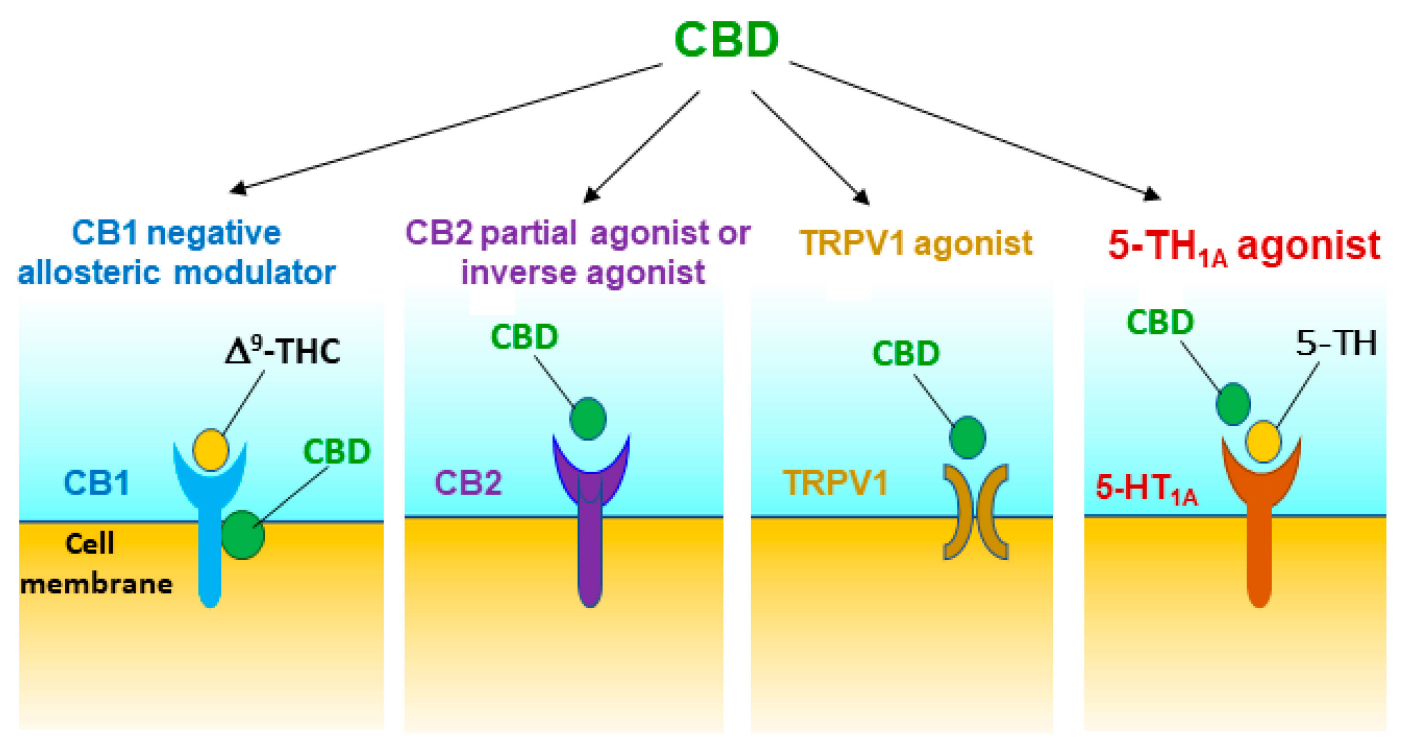

Figure 1. Potential receptor mechanisms underlying CBD's action against drug reward and addiction. The results from in vitro receptor binding and functional intracellular signalling assays and in vivo behavioral studies with pharmacological and transgenic approaches suggest that CBD may act as a CB1R negative allosteric modulator, a CB2R partial agonist or antagonist/inverse agonist, and a TRPV1 and 5- $\mathrm{HT}_{1 \mathrm{~A}}$ receptor agonist. Multiple receptor mechanisms together produce protective and therapeutic effects against drug abuse and addiction.

\subsection{CB2R Mechanism}

In addition, CBD was reported to act as a CB2R antagonist or inverse agonist [41,49], a CB2R agonist or partial agonist [42,60], or a negative allosteric modulator of CB2Rs with $\mathrm{nM}$ binding affinity [44] (Table 1, Figure 1). To further determine the role of CB2R in CBD's action in experimental animals, we used both pharmacological and transgenic approaches. We found that pretreatment with AM630 (a selective CB2R antagonist) prevented CBD's attenuating effects on cocaine self-administration and cocaine-enhanced BSR in rats [37], suggesting that CB2Rs might be involved in CBD's action and CBD itself may act as a functional CB2R agonist. Similarly, pharmacological blockade or genetic deletion of CB2R in CB2-KO mice blocked CBD-induced reduction in oral sucrose self-administration [52]. Systemic administration of JWH133 (a selective CB2R agonist) also produced a dose-dependent reduction in sucrose self-administration in WT but not in CB2-KO mice. Pretreatment with AM630 blocked JWH133-induced reduction in sucrose self-administration. These findings are consistent with previous reports that CB2R antagonism attenuates CBD-induced reductions in food intake, body weight and obesity [61-63], and attenuates CBD-produced neuroprotection [64] (Table 2). 
Table 2. Receptor mechanism studies in vivo in reward-related behaviors in experimental animals.

\begin{tabular}{|c|c|c|}
\hline Receptor Mechanism & Major Findings & References \\
\hline \multirow{7}{*}{ CB1 } & $\begin{array}{c}\text { CBD blocked CB1R up-regulation in rats after extinction from heroin } \\
\text { self-administration }\end{array}$ & [29] \\
\hline & $\begin{array}{l}\text { Repeated treatment with CBD increased CB1R expression in the } \\
\text { striatum }\end{array}$ & [36] \\
\hline & $\begin{array}{l}\text { Deletion of CB1R potentiated CBD-induced reduction in sucrose } \\
\text { self-administration in CB1-KO mice }\end{array}$ & {$[52]$} \\
\hline & $\begin{array}{l}\text { AM251 failed to alter CBD-induced reduction in cocaine } \\
\text { self-administration in rats }\end{array}$ & [37] \\
\hline & $\begin{array}{l}\text { SR141716A failed to alter CBD-potentiated extinction of cocaine- or } \\
\text { amphetamine-induced CPP in rats }\end{array}$ & [38] \\
\hline & $\begin{array}{l}\text { AM251 failed to alter CBD-induced reduction in } 75 \mathrm{mg} / \mathrm{kg} \text { of } \\
\text { cocaine-induced seizure }\end{array}$ & [65] \\
\hline & $\begin{array}{l}\text { AM251 blocked CBD-induced reduction in aggressive behavior caused } \\
\text { by social isolation in mice }\end{array}$ & [66] \\
\hline \multirow{4}{*}{ CB2 } & $\begin{array}{l}\text { Deletion of CB2R blocked CBD-induced reduction in sucrose } \\
\text { self-administration }\end{array}$ & [52] \\
\hline & $\begin{array}{l}\text { AM630 attenuated CBD-induced reduction in cocaine } \\
\text { self-administration }\end{array}$ & [37] \\
\hline & $\begin{array}{l}\text { AM630 attenuated CBD-induced reduction in food intake, body weight } \\
\text { and obesity }\end{array}$ & {$[67,68]$} \\
\hline & $\begin{array}{l}\text { AM630 failed to alter high doses }(75 \mathrm{mg} / \mathrm{kg}) \text { of cocaine-induced } \\
\text { seizure in mice }\end{array}$ & {$[65]$} \\
\hline \multirow[t]{2}{*}{ TRPV1 } & $\begin{array}{l}\text { TRPV1 antagonist blocks CBD-induced reduction in cocaine } \\
\text { self-administration in rats }\end{array}$ & [37] \\
\hline & $\begin{array}{l}\text { TRPV1 deletion attenuates CBD-induced reduction in electrical } \\
\text { shock-induced seizure in mice }\end{array}$ & [69] \\
\hline \multirow{6}{*}{$5-\mathrm{HT}_{1 \mathrm{~A}}$} & $\begin{array}{l}\text { The } 5-\mathrm{HT}_{1 \mathrm{~A}} \text { antagonist, WAY100635, blocked CBD's action in cocaine } \\
\text { self-administration in rats }\end{array}$ & [37] \\
\hline & $\begin{array}{l}\text { WAY100635 attenuated CBD's action on morphine-enhanced brain } \\
\text { stimulation reward in rats }\end{array}$ & [32] \\
\hline & $\begin{array}{l}\text { Deletion of } 5-\mathrm{HT}_{1 \mathrm{~A}} \text { in the DRN abolished cocaine-induced CPP. } 5-\mathrm{HT}_{1 \mathrm{~A}} \\
\text { antagonism in the DRN inhibited cocaine self-administration in rats }\end{array}$ & {$[70]$} \\
\hline & $\begin{array}{l}\text { Intra-NAc CBD inhibited spontaneous DA neuronal firing, which can } \\
\text { be reversed by WAY100635 }\end{array}$ & [71] \\
\hline & WAY100635 attenuated CBD's action in alcohol consumption in rats & [72] \\
\hline & $\begin{array}{l}\text { WAY100635 attenuated CBD-induced reduction in aggressive behavior } \\
\text { caused by social isolation }\end{array}$ & [66] \\
\hline \multirow[t]{2}{*}{ GPR55 } & $\begin{array}{l}\text { GPR55 antagonism did not alter CBD's action in cocaine } \\
\text { self-administration in rats }\end{array}$ & [37] \\
\hline & $\begin{array}{l}\text { GPR55 deletion failed to alter CBD's action in cocaine } \\
\text { self-administration in mice }\end{array}$ & \\
\hline MOR \& DOR & Naloxone had no effect on CBD action in cocaine self-administration & [37] \\
\hline
\end{tabular}

These findings are important, as growing evidence indicates that CB2Rs are expressed in the brain and are functionally involved in drug reward and addiction [73,74]. Particularly, CB2Rs have been found on midbrain dopamine (DA) neurons in the ventral tegmental area (VTA) $[67,68]$ and their projection terminals in the NAc $[75,76]$. Therefore, we have recently proposed that a DA-dependent mechanism may underlie CBD's attenuating effects 
on cocaine reward via a combination of multiple receptor mechanisms, including the CB2R mechanism [37,52]. This hypothesis is supported by our findings that pretreatment with CBD significantly attenuates cocaine-induced increases in extracellular NAc DA [37] and that intra-NAc microinjections of CBD inhibit VTA DA neuronal activity and attenuates amphetamine-induced hyperlocomotion [77]. Importantly, CBD alone does not significantly alter extracellular DA levels in the NAc [37]. This may, in part, explain why CBD itself is neither rewarding nor aversive.

\section{3. $5-H T_{1 A}$ Mechanism}

In addition to $\mathrm{CBD}$ binding to the $\mathrm{CB} 1$ and $\mathrm{CB} 2$ receptors, Russo et al. [48] were the first to report that $\mathrm{CBD}$ also acts as a $5 \mathrm{HT}_{1 \mathrm{~A}}$ receptor agonist. Since then, a number of studies indicated the involvement of $5-\mathrm{HT}_{1 \mathrm{~A}}$ receptors in CBD's action in vivo, primarily its anxiolytic effects [70]. We have recently reported that pretreatment with WAY100135, a selective $5-\mathrm{HT}_{1 \mathrm{~A}}$ antagonist, was able to block CBD-induced reductions in cocaine selfadministration and in cocaine-enhanced BSR, supporting an important role of 5- $\mathrm{HT}_{1 \mathrm{~A}}$ in CBD's action [37] (Table 2). In addition, intra-NAc administration of CBD also significantly inhibits spontaneous mesolimbic DA neuronal activity and burst firing, which can be reversed by $5-\mathrm{HT}_{1 \mathrm{~A}}$ antagonism [71], suggesting that the activation of $5-\mathrm{HT}_{1 \mathrm{~A}}$ receptors by CBD may modulate the mesolimbic DA system, producing the reward-attenuating effects described above (Figure 1).

\subsection{TRPV1 Mechanism}

It was reported that that CBD may also activate TRPV1 (also known as the capsaicin receptor) $[78,79]$. Therefore, we have recently examined this possibility. We found that pretreatment with capsazepine, a selective TRPV1 antagonist, was able to block CBDinduced reduction in cocaine self-administration and BSR [37], suggesting that TRPV1 activation may also contribute to the therapeutic effects of CBD (Figure 1). The precise TRPV1 mechanisms involved in CBD's action in cocaine reward are unclear. As TRPV1 channels are found on glutamatergic neurons in the frontal cortex and on striatal GABAergic neurons [80], one possibility is that CBD may alter brain glutamate and GABA release via TRPV1, leading to a reduction in cocaine reward. Another possibility is that CBD may inhibit fatty acid-binding proteins (FABPs) that mediate anandamide (AEA) transport to its catabolic enzyme fatty acid amide hydrolase (FAAH), leading to an increase in extracellular anandamide (AEA) levels $[46,47,81]$, which subsequently activate both CB1Rs and TRPV1 [82,83], altering cocaine-taking and cocaine-seeking behavior. We should note that CBD displays low affinity to FABPs and low efficacy in inhibiting AEA update [47]. CBD inhibits AEA hydrolysis only at very high concentrations $(\geq 50 \mu \mathrm{M})$ in HeLa cells expressing rat, but not human, FAAH [47], suggesting that this action may play a limited role in CBD's action in addiction-related behavior.

It is unknown how such multiple receptor mechanisms mediates CBD-attenuated effects on cocaine reward. Since CBD displays different binding affinities to different receptors (Table 1), one possibility is that it produces therapeutic effects through different receptor mechanisms at different drug doses. Another possibility is that the receptors discussed above may form functional heteromers or interact at intracellular signal molecule levels if they are co-expressed in a specific phenotype of neurons. Thus, CBD's action at one receptor may alter another receptor's signaling and function.

\section{CBD Inhibits Methamphetamine Reward and Relapse by DA-Related Mechanisms}

Methamphetamine (METH) is another widely abused and highly addictive psychostimulant. It has been reported that CBD at high doses $(80 \mathrm{mg} / \mathrm{kg}$, but not 20 or $40 \mathrm{mg} / \mathrm{kg})$ can attenuate response to meth under a PR schedule of reinforcement, suggesting that $\mathrm{CBD}$ has the ability to reduce motivation and METH reward [84]. CBD can also reduce drug-primed reinstatement of METH-seeking in rats, suggesting its therapeutic potential in relapse prevention [84]. Intracranial injections of CBD directly into the NAc can block 
hyperlocomotion, stereotypy and behavioral sensitization induced by amphetamine [77]. CBD has been also shown to facilitate the extinction of amphetamine CPP [38] and to prevent meth-induced reinstatement of CPP in rats. Intracranial microinjections of CBD into the lateral ventricles attenuated the reinstated preference for meth-related environments under stress conditions (i.e., sleep deprivation) [85].

To date, specific receptor mechanisms underlying CBD's action against METH addictionrelated behaviors have not been reported. Evidence has shown that intra-NAc CBD can inhibit amphetamine-induced hyperlocomotion and behavioral sensitization by regulating downstream phosphorylation of the mTOR/p70S6 kinase signaling pathway within the NAc shell [77]. In addition, rats conditioned with METH show strong CPP associated with upregulation of the Sigma1 receptor and a number of intracellular molecules (such as AKT, p-AKT, GSK- $3 \beta$, p-GSK-3 $\beta$, CREB and p-CREB) in the prefrontal cortex (PFC), VTA, NAc and hippocampus. CBD attenuated METH-induced CPP in a dose-dependent manner by regulating the Sigma1R, p-AKT, p-GSK3 $\beta$ and p-CREB pathways across these brain regions [86]. These important findings suggest that $C B D$ might have therapeutic potential on METH-driven behaviors and can reverse some of the METH-induced neuroplastic changes.

Furthermore, stress- or drug-induced reinstatement of METH CPP has been associated with the upregulation of a number of cytokines in the PFC and hippocampus, including interleukin-1 $\beta$ (IL-1 $\beta$ ), interleukin-6 (IL-6), interleukin-10 (IL-10) and tumor necrosis factor $\alpha(\mathrm{TNF}-\alpha)$ [87]. Interestingly, CBD prevented the upregulation of IL- $1 \beta$, IL-6 and IL-10 mRNA in the PFC, and also TNF- $\alpha$, IL- $1 \beta$ and IL- 6 mRNA in the hippocampus in rats undergoing drug-induced reinstatement. These cytokines are known to modulate the neuronal activity of monoamine neurons (e.g., DA neurons) indirectly by the release of neuroactive molecules from glia cells and directly by activating cytokine receptors located on DA and other monoamine neurons [88-91]. Thus, it has been proposed that METH re-exposure enhances the expression of pro-inflammatory cytokines such as IL- $1 \beta$ and TNF- $\alpha$, leading to the release of neurotransmitters that are involved in the reinstatement of METH. CBD appears to attenuate this form of METH-induced neuroplasticity in the mesocorticolimbic DA system [87].

\section{CBD Attenuates Alcohol Taking Possibly by the CB1, CB2 and 5-HT $1 \mathrm{~A}$ Receptor Mechanisms}

CBD also shows therapeutic potential for the treatment of alcohol use disorder. In a two-bottle paradigm, CBD (60 and $120 \mathrm{mg} / \mathrm{kg}$, i.p.) reduced alcohol consumption and preference in mice. In addition, CBD was effective in reducing oral self-administration of alcohol, relapse and alcohol-induced hypothermia [92]. Males appear to be more sensitive to CBD than females, as acute treatment with $\operatorname{CBD}(30,60,90 \mathrm{mg} / \mathrm{kg})$ attenuated alcohol intake in male mice, but in female mice, $90 \mathrm{mg} / \mathrm{kg}$ CBD was required to inhibit alcohol intake [93]. Interestingly, CBD was found to be effective in reducing context-and stressinduced reinstatement of alcohol-seeking, up to 138 days post-CBD treatment, even though brain CBD levels remained detectable only for 3 days post-treatment [40]. CBD also reduced anxiety and impulsivity in rats with a history of alcohol consumption [40]. However, CBD appears to be ineffective in reducing alcohol-induced locomotor sensitization in mice, unless combined with $\Delta^{9}$-THC (1:1 ratio) [94], suggesting that $\Delta^{9}$-THC can potentiate CBD's action against alcohol.

The receptor mechanisms through which CBD inhibits alcohol intake remain unclear. After chronic CBD administration mice showed a significant reduction of tyrosine hydroxylase (TH) mRNA expression in the VTA and of Oprm1, CB1 and GPR55 in the NAc [92,93]. However, a significant increase in CB2 mRNA was found in the NAc [92]. In addition, a combination of $\mathrm{CBD}$ with naloxone can also reduce alcohol consumption and the associated gene expression of Oprm1 in the NAc, TH in the VTA and 5- $\mathrm{HT}_{1 \mathrm{~A}}$ in the dorsal raphe nucleus [72]. Interestingly, the administration of WAY100635 (a 5- $\mathrm{HT}_{1 \mathrm{~A}}$ antagonist) significantly blocked the action of CBD + naltrexone. Although a causal relationship was not determined in these studies, these findings suggest that the attenuating effects of $\mathrm{CBD}$ 
on alcohol consumption and relapse might be mediated by mechanisms related to CB1, CB2, GPR55, MOR and 5- $\mathrm{HT}_{1 \mathrm{~A}}$ receptors within the mesolimbic system.

In summary, growing evidence indicates that $\mathrm{CBD}$ could be a promising candidate for the treatment of substance use disorders. In experimental animals, CBD displays pharmacological efficacy in attenuation of drug reward and propensity to relapse. The receptor mechanisms underlying CBD action are very complex and are involved in multiple receptors, as reviewed here (Table 2). Pharmacological and transgenic studies indicate that $\mathrm{CB} 1, \mathrm{CB} 2$, TRPV1 and 5- $\mathrm{HT}_{1 \mathrm{~A}}$ receptors are critically involved in CBD acts on in vivo. Blockade or genetic deletion of CB1Rs tends to enhance, while blockade or deletion of CB2R attenuated cocaine or sucrose self-administration, suggesting that CBD may act as an allosteric CB1R antagonist or a CB2R antagonist/inverse agonist or partial agonist (Figure 1). Similarly, pharmacological blockade of TRPV1 or $5-\mathrm{HT}_{1 \mathrm{~A}}$ receptors also attenuates CBD's action in multiple behavioral paradigms of reward and addiction, suggesting that CBD may functionally act as a TRPV1 and 5- $\mathrm{HT}_{1 \mathrm{~A}}$ agonist (Figure 1 ). As stated above, these receptors may functionally modulate VTA DA neuron activity and DA release in the NAc either directly or indirectly [73,95]. Thus, the mesolimbic DA system could act as one of the final common targets underlying CBD's anti-addiction effects. Among the other targets such as GPR55, PPAR $\gamma$, TRPA1, TRPM8, TRPV2, adenosine $\mathrm{A}_{1}$ and $\mathrm{A}_{2 \mathrm{~A}}$, $\mathrm{mu}$ and delta opioid receptors and $\alpha 1$ glycine receptors [50,96-98], CBD displays very low affinity to these receptors with the half maximal effective concentration $\left(\mathrm{EC}_{50}\right)$ or half maximal inhibitory concentration $\left(\mathrm{IC}_{50}\right)$ values of $1-20 \mu \mathrm{M}$, suggesting limited roles of these receptors in CBD's action. There is a lack of behavioral evidence indicating that GPR55 and MORs are involved in CBD action in animal models of addiction [37]. We note that $C B D$ displays high binding affinity to $D A D_{2}$ receptors (with a Ki value of $11 \mathrm{nM}$ for $D_{2}$ high affinity binding sites) and functionally acts as a partial $D_{2} R$ agonist; however, the functional role of $\mathrm{D}_{2}$ receptors in CBD's action has not been explored in vivo. Given that clinical doses (800-1000 mg/day) of CBD are sufficient to occupy the functional $\mathrm{D}_{2}$ High sites and produce antipsychotic effects [45], it is suggested that the $\mathrm{D}_{2} \mathrm{R}$ partial agonist action of CBD may contribute to the therapeutic effects against drugs of abuse. Together, all these findings are promising, while further preclinical studies and future clinical trials are necessary to fully evaluate the safety and efficacy of CBD and the underlying receptor mechanisms in the treatment of substance use disorders.

Funding: This research was supported by the Intramural Research Program (IRP) of the National Institute on Drug Abuse (NIDA) (DA000633-01). There is no external funding used in this research.

Institutional Review Board Statement: This article was reviewed and approved for publication (\#21224) on December 1, 2020 by the Manuscript Approval Program of the National Institute on Drug Abuse Intramural Research Program.

Informed Consent Statement: Not applicable.

Data Availability Statement: Not applicable.

Conflicts of Interest: The authors declare no conflict of interest.

\section{References}

1. Li, H.-L. An archaeological and historical account of cannabis in China. Econ. Bot. 1973, 28, 437-448. [CrossRef]

2. Zuardi, A.W. History of cannabis as a medicine: A review. Braz. J. Psychiatr. 2006, 28, 153-157. [CrossRef] [PubMed]

3. Mikuriya, T.H. Marijuana in medicine: Past, present and future. Calif. Med. 1969, 110, 34-40. [PubMed]

4. Touw, M. The religious and medicinal uses of cannabis in China, India and Tibet. J. Psychoact. Drugs 1981, 13, 23-34. [CrossRef]

5. Gabay, M. The federal controlled substances act: Schedules and pharmacy Registration. Hosp. Pharm. 2013, 48, 473-474. [CrossRef]

6. Gaoni, Y.; Mechoulam, R. Isolation, structure, and partial synthesis of an active constituent of hashish. J. Am. Chem. Soc. 1964, 86, 1646-1647. [CrossRef]

7. Pertwee, R.G. The pharmacology of cannabinoid receptors and their ligands: An overview. Int. J. Obes. 2006, 30, S13. [CrossRef]

8. Mechoulam, R.; Shani, A.; Edery, H.; Grunfeld, Y. Chemical basis of hashish activity. Science 1970, 169, 611-612. [CrossRef]

9. Cunha, J.M.; Carlini, E.A.; Pereira, A.E.; Ramos, O.L.; Pimentel, C.; Gagliardi, R.; Sanvito, W.L.; Lander, N.; Mechoulam, R. Chronic administration of cannabidiol to healthy volunteers and epileptic patients. Pharmacology 1980, 21, 175-185. [CrossRef]

10. Maa, E.; Figi, P. The case for medical marijuana in epilepsy. Epilepsia 2014, 55, 783-786. [CrossRef] 
11. FDA EPIDIOLEX (Cannabidiol) Oral Solution. Highlights of Prescribing Information; June 2018. Available online: https: / / www.accessdata.fda.gov/drugsatfda_docs/label/2018/210365lbl.pdf (accessed on 24 December 2020).

12. Burstein, S. Cannabidiol (CBD) and its analogs: A review of their effects on inflammation. Bioorg. Med. Chem. 2015, 23, 1377-1385. [CrossRef] [PubMed]

13. Zlebnik, N.E.; Cheer, J.F. Beyond the CB1 receptor: Is cannabidiol the answer for disorders of motivation? Annu. Rev. Neurosci. 2016, 39, 1-17. [CrossRef] [PubMed]

14. Maroon, J.; Bost, J. Review of the neurological benefits of phytocannabinoids. Surg. Neurol. Int. 2018, 9, 91. [CrossRef] [PubMed]

15. Russo, E.B. Cannabis therapeutics and the future of neurology. Front. Integr. Neurosci. 2018, 12. [CrossRef]

16. Mandolini, G.M.; Lazzaretti, M.; Pigoni, A.; Oldani, L.; Delvecchio, G.; Brambilla, P. Pharmacological properties of cannabidiol in the treatment of psychiatric disorders: A critical overview. Epidemiol. Psychiatr. Sci. 2018, 27, 327-335. [CrossRef]

17. Calpe-López, C.; García-Pardo, M.P.; Aguilar, M.A. Cannabidiol treatment might promote resilience to cocaine and methamphetamine use disorders: A review of possible mechanisms. Molecules 2019, 24, 2583. [CrossRef]

18. Chye, Y.; Christensen, E.; Solowij, N.; Yücel, M. The endocannabinoid system and cannabidiol's promise for the treatment of substance use disorder. Front. Psychiatr. 2019, 10. [CrossRef]

19. Elsaid, S.; Kloiber, S.; Le Foll, B. Effects of cannabidiol (CBD) in neuropsychiatric disorders: A review of pre-clinical and clinical findings. Prog. Mol. Biol. Transl. Sci 2019, 167, 25-75. [CrossRef]

20. Rodrigues, L.A.; Caroba, M.E.S.; Taba, F.K.; Filev, R.; Gallassi, A.D. Evaluation of the potential use of cannabidiol in the treatment of cocaine use disorder: A systematic review. Pharmacol. Biochem. Behav. 2020, 196. [CrossRef]

21. Hurd, Y.L.; Yoon, M.; Manini, A.F.; Hernandez, S.; Olmedo, R.; Ostman, M.; Jutras-Aswad, D. Early phase in the development of cannabidiol as a treatment for addiction: Opioid relapse takes initial center stage. Neurotherapeutics 2015, 12, 807-815. [CrossRef]

22. Prud'homme, M.; Cata, R.; Jutras-Aswad, D. Cannabidiol as an Intervention for Addictive Behaviors: A systematic review of the evidence. Subst. Abus. 2015, 9, 33-38. [CrossRef] [PubMed]

23. Freeman, A.M.; Petrilli, K.; Lees, R.; Hindocha, C.; Mokrysz, C.; Curran, H.V.; Saunders, R.; Freeman, T.P. How does cannabidiol (CBD) influence the acute effects of delta-9-tetrahydrocannabinol (THC) in humans? A systematic review. Neurosci. Biobehav. Rev. 2019, 107, 696-712. [CrossRef]

24. Turna, J.; Syan, S.K.; Frey, B.N.; Rush, B.; Costello, M.J.; Weiss, M.; MacKillop, J. Cannabidiol as a novel candidate alcohol use disorder pharmacotherapy: A systematic review. Alcohol. Clin. Exp. Res. 2019, 43, 550-563. [CrossRef]

25. Nona, C.N.; Hendershot, C.S.; Le Foll, B. Effects of cannabidiol on alcohol-related outcomes: A review of preclinical and human research. Exp. Clin. Psychopharmacol. 2019, 27, 359-369. [CrossRef]

26. Hine, B.; Torrelio, M.; Gershon, S. Differential effect of cannabinol and cannabidiol on THC-induced responses during abstinence in morphine-dependent rats. Res. Commun. Chem. Pathol. Pharmacol. 1975, 12, 185-188. [PubMed]

27. Hine, B.; Torrelio, M.; Gershon, S. Interactions between cannabidiol and $\Delta 9$-THC during abstinence in morphine-dependent rats. Life Sci. 1975, 17, 851-857. [CrossRef]

28. Bhargava, H.N. Effect of some cannabinoids on naloxone-precipitated abstinence in morphine-dependent mice. Psychopharmacology 1976, 49, 267-270. [CrossRef] [PubMed]

29. Ren, Y.; Whittard, J.; Higuera-Matas, A.; Morris, C.V.; Hurd, Y.L. Cannabidiol, a nonpsychotropic component of cannabis, inhibits cue-induced heroin seeking and normalizes discrete mesolimbic neuronal disturbances. J. Neurosci. 2009, 29, 14764-14769. [CrossRef] [PubMed]

30. Markos, J.R.; Harris, H.M.; Gul, W.; ElSohly, M.A.; Sufka, K.J. Effects of cannabidiol on morphine conditioned place preference in mice. Planta Med. 2018, 84, 221-224. [CrossRef]

31. De Carvalho, C.R.; Takahashi, R.N. Cannabidiol disrupts the reconsolidation of contextual drug-associated memories in Wistar rats. Addict. Biol. 2017, 22, 742-751. [CrossRef]

32. Katsidoni, V.; Apazoglou, K.; Panagis, G. Role of serotonin 5-HT2A and 5-HT2C receptors on brain stimulation reward and the reward-facilitating effect of cocaine. Psychopharmacology 2011, 213, 337-354. [CrossRef] [PubMed]

33. Pellinen, P.; Honkakoski, P.; Stenbäck, F.; Niemitz, M.; Alhava, E.; Pelkonen, O.; Lang, M.A.; Pasanen, M. Cocaine N-demethylation and the metabolism-related hepatotoxicity can be prevented by cytochrome P450 3A inhibitors. Eur. J. Pharmacol. 1994, 270, 35-43. [CrossRef]

34. Bornheim, L.M. Effect of cytochrome P450 inducers on cocaine-mediated hepatotoxicity. Toxicol. Appl. Pharmacol. 1998, 150, 158-165. [CrossRef] [PubMed]

35. Mahmud, A.; Gallant, S.; Sedki, F.; D'Cunha, T.; Shalev, U. Effects of an acute cannabidiol treatment on cocaine self-administration and cue-induced cocaine seeking in male rats. J. Psychopharmacol. 2017, 31, 96-104. [CrossRef] [PubMed]

36. Luján, M.Á.; Castro-Zavala, A.; Alegre-Zurano, L.; Valverde, O. Repeated Cannabidiol treatment reduces cocaine intake and modulates neural proliferation and CB1R expression in the mouse hippocampus. Neuropharmacology 2018, 143, 163-175. [CrossRef] [PubMed]

37. Galaj, E.; Bi, G.-H.; Yang, H.-J.; Xi, Z.-X. Cannabidiol attenuates the rewarding effects of cocaine in rats by CB2, 5-HT1A and TRPV1 receptor mechanisms. Neuropharmacology 2020, 167. [CrossRef]

38. Parker, L.A.; Burton, P.; Sorge, R.E.; Yakiwchuk, C.; Mechoulam, R. Effect of low doses of delta9-tetrahydrocannabinol and cannabidiol on the extinction of cocaine-induced and amphetamine-induced conditioned place preference learning in rats. Psychopharmacology 2004, 175, 360-366. [CrossRef] 
39. Gerdeman, G.L.; Schechter, J.B.; French, E.D. Context-specific reversal of cocaine sensitization by the CB1 cannabinoid receptor antagonist rimonabant. Neuropsychopharmacology 2008, 33, 2747-2759. [CrossRef]

40. Gonzalez-Cuevas, G.; Martin-Fardon, R.; Kerr, T.M.; Stouffer, D.G.; Parsons, L.H.; Hammell, D.C.; Banks, S.L.; Stinchcomb, A.L.; Weiss, F. Unique treatment potential of cannabidiol for the prevention of relapse to drug use: Preclinical proof of principle. Neuropsychopharmacology 2018, 43, 2036-2045. [CrossRef]

41. Thomas, A.; Baillie, G.L.; Phillips, A.M.; Razdan, R.K.; Ross, R.A.; Pertwee, R.G. Cannabidiol displays unexpectedly high potency as an antagonist of CB1 and CB2 receptor agonists in vitro. Br. J. Pharmacol. 2007, 150, 613-623. [CrossRef]

42. Tham, M.; Yilmaz, O.; Alaverdashvili, M.; Kelly, M.E.M.; Denovan-Wright, E.M.; Laprairie, R.B. Allosteric and orthosteric pharmacology of cannabidiol and cannabidiol-dimethylheptyl at the type 1 and type 2 cannabinoid receptors. Br. J. Pharmacol. 2019, 176, 1455-1469. [CrossRef] [PubMed]

43. Laprairie, R.B.; Bagher, A.M.; Kelly, M.E.M.; Denovan-Wright, E.M. Cannabidiol is a negative allosteric modulator of the cannabinoid CB1 receptor. Br. J. Pharmacol. 2015, 172, 4790-4805. [CrossRef] [PubMed]

44. Martínez-Pinilla, E.; Varani, K.; Reyes-Resina, I.; Angelats, E.; Vincenzi, F.; Ferreiro-Vera, C.; Oyarzabal, J.; Canela, E.I.; Lanciego, J.L.; Nadal, X.; et al. Binding and Signaling Studies Disclose a Potential Allosteric Site for Cannabidiol in Cannabinoid CB2 Receptors. Front. Pharmacol. 2017, 8. [CrossRef] [PubMed]

45. Seeman, P. Cannabidiol is a partial agonist at dopamine D2High receptors, predicting its antipsychotic clinical dose. Transl. Psychiatry 2016, 6, e920. [CrossRef] [PubMed]

46. Bisogno, T.; Hanuš, L.; Petrocellis, L.D.; Tchilibon, S.; Ponde, D.E.; Brandi, I.; Moriello, A.S.; Davis, J.B.; Mechoulam, R.; Marzo, V.D. Molecular targets for cannabidiol and its synthetic analogues: Effect on vanilloid VR1 receptors and on the cellular uptake and enzymatic hydrolysis of anandamide. Br. J. Pharmacology 2001, 134, 845-852. [CrossRef]

47. Elmes, M.W.; Kaczocha, M.; Berger, W.T.; Leung, K.; Ralph, B.P.; Wang, L.; Sweeney, J.M.; Miyauchi, J.T.; Tsirka, S.E.; Ojima, I.; et al. Fatty acid-binding proteins (FABPs) are intracellular carriers for $\triangle 9$-tetrahydrocannabinol (THC) and cannabidiol (CBD). $J$. Biol. Chem. 2015, 290, 8711-8721. [CrossRef]

48. Russo, E.B.; Burnett, A.; Hall, B.; Parker, K.K. Agonistic Properties of cannabidiol at 5-HT1a receptors. Neurochem. Res. 2005, 30, 1037-1043. [CrossRef]

49. Pertwee, R.G. The diverse CB1 and CB2 receptor pharmacology of three plant cannabinoids: $\Delta$ 9-tetrahydrocannabinol, cannabidiol and $\Delta$-tetrahydrocannabivarin. Br. J. Pharmacol. 2008, 153, 199-215. [CrossRef]

50. Kathmann, M.; Flau, K.; Redmer, A.; Tränkle, C.; Schlicker, E. Cannabidiol is an allosteric modulator at mu- and delta-opioid receptors. Naunyn. Schmied. Arch. Pharmacol. 2006, 372, 354-361. [CrossRef]

51. Straiker, A.; Mitjavila, J.; Yin, D.; Gibson, A.; Mackie, K. Aiming for allosterism: Evaluation of allosteric modulators of CB1 in a neuronal model. Pharmacol. Res. 2015, 99, 370-376. [CrossRef]

52. Bi, G.-H.; Galaj, E.; He, Y.; Xi, Z.-X. Cannabidiol inhibits sucrose self-administration by CB1 and CB2 receptor mechanisms in rodents. Addict. Biol. 2019, e12783. [CrossRef]

53. Xi, Z.-X.; Spiller, K.; Pak, A.C.; Gilbert, J.; Dillon, C.; Li, X.; Peng, X.-Q.; Gardner, E.L. Cannabinoid CB1 receptor antagonists attenuate cocaine's rewarding effects: Experiments with self-administration and brain-stimulation reward in rats. Neuropsychopharmacology 2008, 33, 1735-1745. [CrossRef] [PubMed]

54. Casarotto, P.C.; Gomes, F.V.; Resstel, L.B.M.; Guimarães, F.S. Cannabidiol inhibitory effect on marble-burying behaviour: Involvement of CB1 receptors. Behav. Pharmacol. 2010, 21, 353-358. [CrossRef] [PubMed]

55. Lesscher, H.M.B.; Hoogveld, E.; Burbach, J.P.H.; van Ree, J.M.; Gerrits, M.A.F.M. Endogenous cannabinoids are not involved in cocaine reinforcement and development of cocaine-induced behavioural sensitization. Eur. Neuropsychopharmacol. 2005, $15,31-37$. [CrossRef] [PubMed]

56. Filip, M.; Gołda, A.; Zaniewska, M.; McCreary, A.C.; Nowak, E.; Kolasiewicz, W.; Przegaliński, E. Involvement of cannabinoid CB1 receptors in drug addiction: Effects of rimonabant on behavioral responses induced by cocaine. Pharmacol. Rep. 2006, 58, 806-819. [PubMed]

57. Adamczyk, P.; Miszkiel, J.; McCreary, A.C.; Filip, M.; Papp, M.; Przegaliński, E. The effects of cannabinoid CB1, CB2 and vanilloid TRPV1 receptor antagonists on cocaine addictive behavior in rats. Brain Res. 2012, 1444, 45-54. [CrossRef] [PubMed]

58. Thapa, D.; Toguri, J.T.; Szczesniak, A.M.; Kelly, M.E. The Non-psychoactive phytocannabinoid, cannabidiol (CBD), and the synthetic derivatives, HU308 and CBD-DMH, reduces hyperalgesia and inflammation in a mouse model of corneal injury. FASEB J. 2017, 31. [CrossRef]

59. De Gregorio, D.; McLaughlin, R.J.; Posa, L.; Ochoa-Sanchez, R.; Enns, J.; Lopez-Canul, M.; Aboud, M.; Maione, S.; Comai, S.; Gobbi, G. Cannabidiol modulates serotonergic transmission and reverses both allodynia and anxiety-like behavior in a model of neuropathic pain. Pain 2019, 160, 136-150. [CrossRef]

60. Navarro, G.; Reyes-Resina, I.; Rivas-Santisteban, R.; Sánchez de Medina, V.; Morales, P.; Casano, S.; Ferreiro-Vera, C.; Lillo, A.; Aguinaga, D.; Jagerovic, N.; et al. Cannabidiol skews biased agonism at cannabinoid CB1 and CB2 receptors with smaller effect in CB1-CB2 heteroreceptor complexes. Biochem. Pharmacol. 2018, 157, 148-158. [CrossRef]

61. Ishiguro, H.; Carpio, O.; Horiuchi, Y.; Shu, A.; Higuchi, S.; Schanz, N.; Benno, R.; Arinami, T.; Onaivi, E.S. A nonsynonymous polymorphism in cannabinoid CB2 receptor gene is associated with eating disorders in humans and food intake is modified in mice by its ligands. Synapse 2010, 64, 92-96. [CrossRef] 
62. Ignatowska-Jankowska, B.; Jankowski, M.M.; Swiergiel, A.H. Cannabidiol decreases body weight gain in rats: Involvement of CB2 receptors. Neurosci. Lett. 2011, 490, 82-84. [CrossRef] [PubMed]

63. Deveaux, V.; Cadoudal, T.; Ichigotani, Y.; Teixeira-Clerc, F.; Louvet, A.; Manin, S.; Nhieu, J.T.-V.; Belot, M.P.; Zimmer, A.; Even, P.; et al. Cannabinoid CB2 receptor potentiates obesity-associated inflammation, insulin resistance and hepatic steatosis. PLoS ONE 2009, 4, e5844. [CrossRef] [PubMed]

64. Castillo, A.; Tolón, M.R.; Fernández-Ruiz, J.; Romero, J.; Martinez-Orgado, J. The neuroprotective effect of cannabidiol in an in vitro model of newborn hypoxic-ischemic brain damage in mice is mediated by $\mathrm{CB}(2)$ and adenosine receptors. Neurobiol. Dis. 2010, 37, 434-440. [CrossRef] [PubMed]

65. Gobira, P.H.; Vilela, L.R.; Gonçalves, B.D.; Santos, R.P.; de Oliveira, A.C.; Vieira, L.B.; Aguiar, D.C.; Crippa, J.A.; Moreira, F.A. Cannabidiol, a Cannabis sativa constituent, inhibits cocaine-induced seizures in mice: Possible role of the mTOR pathway and reduction in glutamate release. Neurotoxicology 2015, 50, 116-121. [CrossRef]

66. Hartmann, A.; Lisboa, S.F.; Sonego, A.B.; Coutinho, D.; Gomes, F.V.; Guimarães, F.S. Cannabidiol attenuates aggressive behavior induced by social isolation in mice: Involvement of 5-HT1A and CB1 receptors. Prog. Neuropsychopharmacol. Biol. Psychiatry 2019, 94, 109637. [CrossRef]

67. Zhang, H.-Y.; Gao, M.; Liu, Q.-R.; Bi, G.-H.; Li, X.; Yang, H.-J.; Gardner, E.L.; Wu, J.; Xi, Z.-X. Cannabinoid CB2 receptors modulate midbrain dopamine neuronal activity and dopamine-related behavior in mice. Proc. Natl. Acad. Sci. USA 2014, 111, E5007-E5015. [CrossRef]

68. Zhang, H.-Y.; Gao, M.; Shen, H.; Bi, G.-H.; Yang, H.-J.; Liu, Q.-R.; Wu, J.; Gardner, E.L.; Bonci, A.; Xi, Z.-X. Expression of functional cannabinoid CB2 receptor in VTA dopamine neurons in rats. Addict. Biol. 2017, 22, 752-765. [CrossRef]

69. Gray, R.A.; Stott, C.G.; Jones, N.A.; Di Marzo, V.; Whalley, B.J. Anticonvulsive properties of cannabidiol in a model of generalized seizure are transient receptor potential vanilloid 1 dependent. Cannabis Cannabinoid Res. 2020, 5, 145-149. [CrossRef]

70. You, I.-J.; Wright, S.R.; Garcia-Garcia, A.L.; Tapper, A.R.; Gardner, P.D.; Koob, G.F.; David Leonardo, E.; Bohn, L.M.; Wee, S. 5-HT1A autoreceptors in the dorsal raphe nucleus convey vulnerability to compulsive cocaine seeking. Neuropsychopharmacology 2016, 41, 1210-1222. [CrossRef]

71. Norris, C.; Loureiro, M.; Kramar, C.; Zunder, J.; Renard, J.; Rushlow, W.; Laviolette, S.R. Cannabidiol modulates fear memory formation through interactions with serotonergic transmission in the mesolimbic system. Neuropsychopharmacology 2016, 41, 2839-2850. [CrossRef]

72. Viudez-Martínez, A.; García-Gutiérrez, M.S.; Fraguas-Sánchez, A.I.; Torres-Suárez, A.I.; Manzanares, J. Effects of cannabidiol plus naltrexone on motivation and ethanol consumption. Br. J. Pharmacol. 2018, 175, 3369-3378. [CrossRef] [PubMed]

73. Jordan, C.; Xi, Z.X. Progress in brain cannabinoid CB2 receptors: From gene to behavior. Neurosci. Biobehav. Rev. 2019, 98, 208-220. [CrossRef] [PubMed]

74. Manzanares, J.; Cabañero, D.; Puente, N.; García-Gutiérrez, M.S.; Grandes, P.; Maldonado, R. Role of the endocannabinoid system in drug addiction. Biochem. Pharmacol. 2018, 157, 108-121. [CrossRef] [PubMed]

75. Aracil-Fernández, A.; Trigo, J.M.; García-Gutiérrez, M.S.; Ortega-Álvaro, A.; Ternianov, A.; Navarro, D.; Robledo, P.; Berbel, P.; Maldonado, R.; Manzanares, J. Decreased cocaine motor sensitization and self-administration in mice overexpressing cannabinoid $\mathrm{CB}_{2}$ receptors. Neuropsychopharmacology 2012, 37, 1749-1763. [CrossRef] [PubMed]

76. Foster, D.J.; Wilson, J.M.; Remke, D.H.; Mahmood, M.S.; Uddin, M.J.; Wess, J.; Patel, S.; Marnett, L.J.; Niswender, C.M.; Jones, C.K.; et al. Antipsychotic-like effects of M4 positive allosteric modulators are mediated by CB2 receptor-dependent inhibition of dopamine release. Neuron 2016, 91, 1244-1252. [CrossRef]

77. Renard, J.; Loureiro, M.; Rosen, L.G.; Zunder, J.; de Oliveira, C.; Schmid, S.; Rushlow, W.J.; Laviolette, S.R. Cannabidiol counteracts amphetamine-induced neuronal and behavioral sensitization of the mesolimbic dopamine pathway through a novel mTOR/p70S6 kinase signaling pathway. J. Neurosci. 2016, 36, 5160-5169. [CrossRef]

78. Iannotti, F.A.; Hill, C.L.; Leo, A.; Alhusaini, A.; Soubrane, C.; Mazzarella, E.; Russo, E.; Whalley, B.J.; Di Marzo, V.; Stephens, G.J. Nonpsychotropic plant cannabinoids, cannabidivarin (CBDV) and cannabidiol (CBD), activate and desensitize transient receptor potential vanilloid 1 (TRPV1) channels in vitro: Potential for the treatment of neuronal hyperexcitability. ACS Chem. Neurosci. 2014, 5, 1131-1141. [CrossRef]

79. De Petrocellis, L.; Ligresti, A.; Moriello, A.S.; Allarà, M.; Bisogno, T.; Petrosino, S.; Stott, C.G.; Di Marzo, V. Effects of cannabinoids and cannabinoid-enriched Cannabis extracts on TRP channels and endocannabinoid metabolic enzymes. Br. J. Pharmacol. 2011, 163, 1479-1494. [CrossRef]

80. Edwards, J.G. TRPV1 in the central nervous system: Synaptic plasticity, function, and pharmacological implications. Prog. Drug Res. 2014, 68, 77-104.

81. Bisogno, T.; Maccarrone, M. Latest advances in the discovery of fatty acid amide hydrolase inhibitors. Exp. Opin. Drug Discov. 2013, 8, 509-522. [CrossRef]

82. Arnold, J.C. The role of endocannabinoid transmission in cocaine addiction. Pharmacol. Biochem. Behav. 2005, 81, 396-406. [CrossRef] [PubMed]

83. Onaivi, E.S. An endocannabinoid hypothesis of drug reward and drug addiction. Ann. N. Y. Acad. Sci. 2008, $1139,412-421$. [CrossRef] [PubMed] 
84. Hay, G.L.; Baracz, S.J.; Everett, N.A.; Roberts, J.; Costa, P.A.; Arnold, J.C.; McGregor, I.S.; Cornish, J.L. Cannabidiol treatment reduces the motivation to self-administer methamphetamine and methamphetamine-primed relapse in rats. J. Psychopharmacol. 2018, 32, 1369-1378. [CrossRef] [PubMed]

85. Karimi-Haghighi, S.; Haghparast, A. Cannabidiol inhibits priming-induced reinstatement of methamphetamine in REM sleep deprived rats. Prog. Neuropsychopharmacol. Biol. Psychiatry 2018, 82, 307-313. [CrossRef]

86. Yang, G.; Liu, L.; Zhang, R.; Li, J.; Leung, C.-K.; Huang, J.; Li, Y.; Shen, B.; Zeng, X.; Zhang, D. Cannabidiol attenuates methamphetamine-induced conditioned place preference via the Sigma1R/AKT/GSK-3 $\beta / C R E B$ signaling pathway in rats. Toxicol. Res. 2020, 9, 202-211. [CrossRef]

87. Karimi-Haghighi, S.; Dargahi, L.; Haghparast, A. Cannabidiol modulates the expression of neuroinflammatory factors in stressand drug-induced reinstatement of methamphetamine in extinguished rats. Addict. Biol. 2020, 25, e12740. [CrossRef]

88. Palazzolo, D.L.; Quadri, S.K. Interleukin-1 stimulates catecholamine release from the hypothalamus. Life Sci. 1990, 47, 2105-2109. [CrossRef]

89. Shintani, F.; Kanba, S.; Nakaki, T.; Nibuya, M.; Kinoshita, N.; Suzuki, E.; Yagi, G.; Kato, R.; Asai, M. Interleukin-1 beta augments release of norepinephrine, dopamine, and serotonin in the rat anterior hypothalamus. J. Neurosci. 1993, 13, 3574-3581. [CrossRef]

90. Benjamins, J.A. Direct effects of secretory products of immune cells on neurons and glia. J. Neurolog. Sci. 2013, 333, 30-36. [CrossRef]

91. Wang, X.; Northcutt, A.L.; Cochran, T.A.; Zhang, X.; Fabisiak, T.J.; Haas, M.E.; Amat, J.; Li, H.; Rice, K.C.; Maier, S.F.; et al. Methamphetamine activates toll-like receptor 4 to induce central immune signaling within the ventral tegmental area and contributes to extracellular dopamine increase in the nucleus accumbens shell. ACS Chem. Neurosci. 2019, 10, 3622-3634. [CrossRef]

92. Viudez-Martínez, A.; García-Gutiérrez, M.S.; Navarrón, C.M.; Morales-Calero, M.I.; Navarrete, F.; Torres-Suárez, A.I.; Manzanares, J. Cannabidiol reduces ethanol consumption, motivation and relapse in mice. Addict. Biol. 2018, 23, 154-164. [CrossRef] [PubMed]

93. Viudez-Martínez, A.; García-Gutiérrez, M.S.; Manzanares, J. Gender differences in the effects of cannabidiol on ethanol binge drinking in mice. Addict. Biol. 2020, 25, e12765. [CrossRef] [PubMed]

94. Filev, R.; Engelke, D.S.; Da Silveira, D.X.; Mello, L.E.; Santos-Junior, J.G. THC inhibits the expression of ethanol-induced locomotor sensitization in mice. Alcohol 2017, 65, 31-35. [CrossRef] [PubMed]

95. Galaj, E.; Xi, Z.-X. Potential of cannabinoid receptor ligands as treatment for substance use disorders. CNS Drugs 2019, 33, 1001-1030. [CrossRef]

96. De Almeida, D.L.; Devi, L.A. Diversity of molecular targets and signaling pathways for CBD. Pharmacol. Res. Perspect. 2020, 8 , e00682. [CrossRef]

97. Izzo, A.A.; Borrelli, F.; Capasso, R.; Di Marzo, V.; Mechoulam, R. Non-psychotropic plant cannabinoids: New therapeutic opportunities from an ancient herb. Trends Pharmacol. Sci. 2009, 30, 515-527. [CrossRef]

98. Ryberg, E.; Larsson, N.; Sjögren, S.; Hjorth, S.; Hermansson, N.-O.; Leonova, J.; Elebring, T.; Nilsson, K.; Drmota, T.; Greasley, P.J. The orphan receptor GPR55 is a novel cannabinoid receptor. Br. J. Pharmacol. 2007, 152, 1092-1101. [CrossRef] 